\title{
From Newsroom to Classroom
}

\author{
Anastasia Thanukos
}

Published online: 24 June 2009

(C) The Author(s) 2009. This article is published with open access at Springerlink.com

Keywords Teaching $\cdot$ Curricula $\cdot$ Applications of evolution

Want a great example of evolution for your classroom? If we are guided by our textbooks, we should look to the radiation of Darwin's finches (Grant and Grant 2008), the return of whales to the water (Thewissen 1998), the evolution of modern horses from their tiny ancestors (MacFadden 2005), or some similar well-established example for a case study. But are these sorts of illustrations the most compelling to students? Though such classic examples of evolution have more than earned their keep in the biology classroom, they are also removed from students' everyday lives. Hyracotherium, for example, may fascinate some students but leave others wondering why they need to know this stuff. Just how relevant is a 50-million-year-old horse to a 14-year-old's fastpaced media-driven world?

For this curriculum-themed issue, "Views from Understanding Evolution" departs from our usual format to introduce Evo in the News (Fig. 1) - a collaborative project of the UC Museum of Paleontology and the National Evolutionary Synthesis Center (NESCent). Evo in the News aims to help high school and college teachers bring current and relevant examples of evolution and evolutionary research into their classrooms to help teach basic concepts in evolutionary biology. Archives are freely available on the Understanding Evolution website (http://evolution.berkeley. edu/), and the latest updates can be received via a free

A. Thanukos $(\bowtie)$

University of California Museum of Paleontology,

1101 Valley Life Sciences Building,

Berkeley, CA 94720-4780, USA

e-mail: thanukos@berkeley.edu

URL: http://evolution.berkeley.edu subscription service (http://evolution.berkeley.edu/evolibrary/ subscribe/email_signup.php).

\section{Current Events, not Ancient History}

Educational research advocates engaging students by showing them how important concepts can be used to make sense of real problems and situations (National Research Council 1999). Using examples with direct links to students' lives may raise their interest in the topic (Hillis 2007), increase their motivation to learn (National Research Council 2003), and encourage them to pursue science, technology, engineering, and math careers (STEM), as urgently recommended to bolster America's scientific and technological infrastructure (Project Kaleidoscope 2006). Unfortunately, bringing current issues and events into the science classroom is often a challenge. Textbooks aim to keep up with advances in the field, but they are often thwarted by the rapid pace at which science moves. Scientific journals that describe cutting-edge, relevant evolutionary research come out daily - but it is difficult for most science teachers to translate these often complex and jargon-filled articles into something appropriate for the classroom. And, at the most basic level, the concerns and issues of interest to students and society are continually evolving. By the time that instructors have access to science teaching materials leveraging student interest in, for example, an emerging virus like swine flu or SARS, the threat and interest level are likely to have waned. How is a teacher to keep up?

The Evo in the News program circumvents these problems and lag times by providing a freely available suite of teaching resources (including lessons, readers, and video podcasts) on basic evolutionary concepts that 
Fig. 1 May 2009 edition of Evo in the News. This article explored the difference between phenotypic plasticity and evolutionary change in relation to popular reporting on climate change

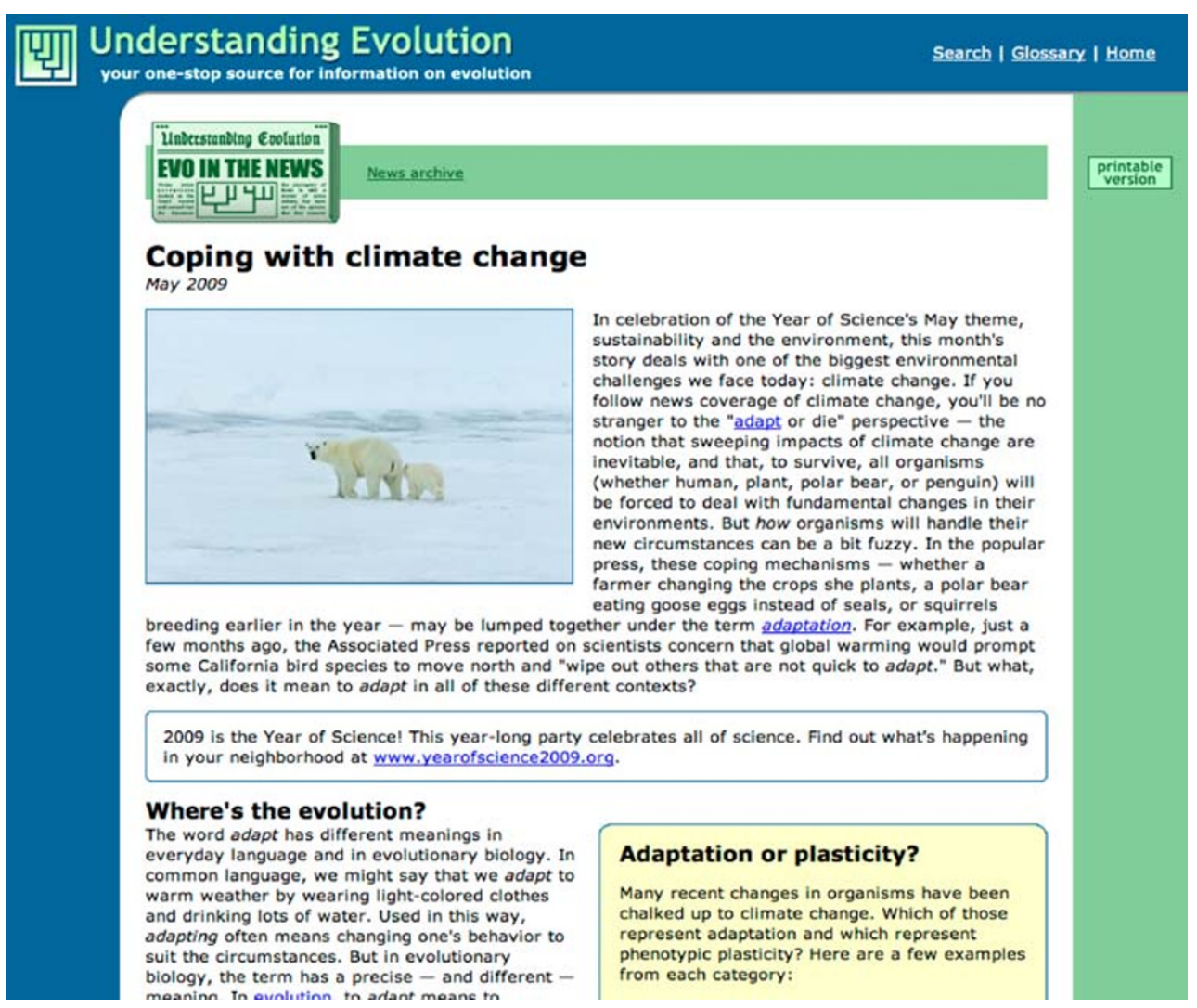

capitalize on current events and come out on a monthly basis during the school year. Some Evo in the News briefs cover a hot topic in evolutionary research that has made it into the popular press in the preceding month (e.g., the discovery of Tiktaalik or new research on the origins of HIV; Daeschler et al. 2006; Worobey et al. 2008). In these cases, Evo in the News provides an explanation of the research in student-friendly terms, addresses the basic evolutionary concepts behind the research, and explains its relevance and importance. Of course, when some outlets in the popular media distort or misrepresent evolutionary research (e.g., when the discovery of a new hominid fossil is erroneously heralded as "challenging evolutionary theory"; Borenstein 2007; Spoor et al. 2007), Evo in the News explains the science behind the hype and why particular evolutionary issues are likely to be misinterpreted. Other news briefs address issues in the news that do not at first seem to have anything to do with evolution to reveal the "evolution behind the scenes"-which frequently gets short shrift in the popular press. For example, during National Breast Cancer Awareness Month, Evo in the News provided an evolutionary perspective on cancer; after major methicillin-resistant Staphylococcus aureus (MRSA) outbreaks, Evo in the News explained the evolution of this bacterial strain; and when six medical workers were sentenced to death in a Libyan trial, Evo in the News dealt with the evolutionary evidence that should have exonerated them. All concepts and news stories addressed are appropriate for high school, advanced placement biology, and/or college biology classes.

More than thirty-five Evo in the News stories are currently archived on the Understanding Evolution website (http://evolution.berkeley.edu/evolibrary/news/ newsarchive_01). They address current events as wideranging as genetic engineering, conservation legislation, disease outbreak, DNA fingerprinting for criminal prosecution, and chemical engineering. Through the lens of these current events, the news briefs deal with fundamental evolutionary concepts, such as natural selection, mutation, genetic drift, speciation, evolutionary fitness, and phylogenetics. In the summer months, updates are added to these stories to keep pace with recent developments and maintain their relevance as an archived resource.

\section{Tools for Teaching}

Each Evo in the News item comes with a set of freely available supplemental materials to help teachers integrate the item into their curricula. In addition to glossary definitions and explanatory graphics (Fig. 2), each news brief comes with:

- Links to freely available news and journal articlesstudents who may not be familiar with the current event 
Fig. 2 Explanatory graphic from the November 2007 edition of Evo in the News. This article explained the evolution behind genetic ancestry tests. a Ancestral sources of nuclear DNA. b Ancestral sources of mitochondrial DNA. Illustration reproduced with permission from the Understanding Evolution website

\section{A. Nuclear DNA is inherited from all ancestors.}

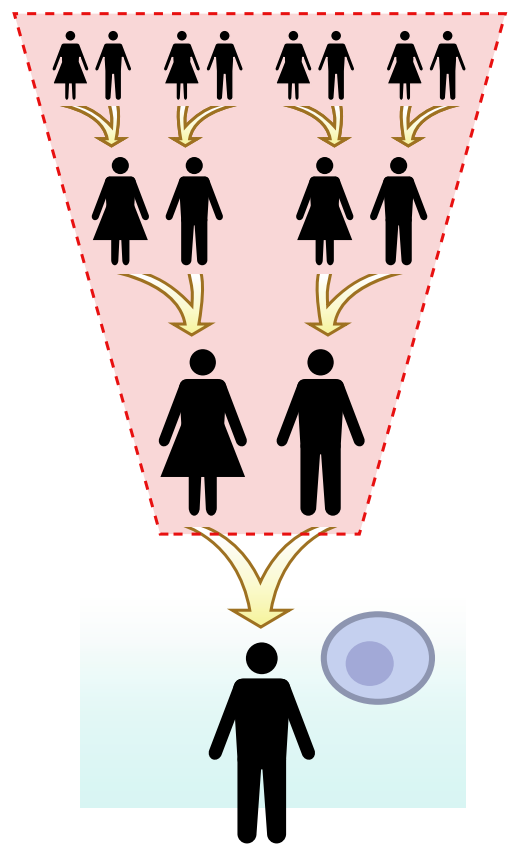

B. Mitochondrial DNA is inherited from a single lineage.

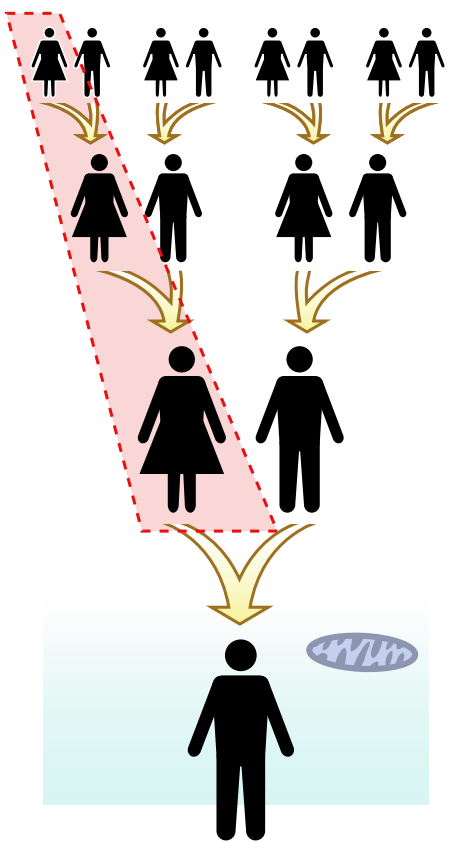

that is the subject of a particular article can use popular press articles to get background information. Journal articles, when available, provide access to original scientific research.

- Links to Understanding Evolution resources-these readers and interactive features are written for students and provide additional background information on relevant evolutionary concepts.

- Discussion and extension questions - these questions can be used to stimulate class discussion on a news brief or can be assigned to students individually or in groups.

- Lessons and teaching resources - these freely available lessons have been vetted by a panel of teachers and can be used to relate the news item to other aspects of the curriculum or give students extra help learning particular key concepts.

In addition, recent news briefs are supplemented by a short video podcast produced by NESCent. These podcasts vary in format slightly, but most are between five and fifteen minutes long and consist of a brief introduction to the topic, followed by an interview with a scientist whose research is closely related to the topic of the news brief. For example, the April 2009 story on the evolution behind biofuel production featured an interview with Sydnor Withers of the Great Lakes Bioenergy Research Center, who explained how his laboratory uses directed evolution to develop ways of building biofuels more efficiently (Fig. 3). These interviews provide students with a glimpse into the process of science and help give science a human face, while reinforcing central evolutionary concepts discussed in the news brief.

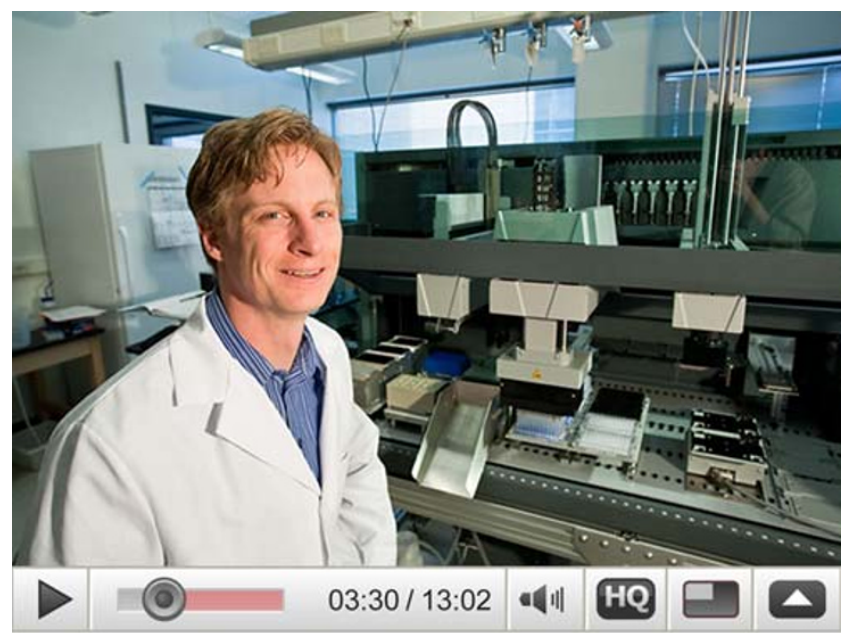

Video podcast on biofuels provided by the National Evolutionary Synthesis Center (NESCent). To learn more, visit the NESCent website.

Fig. 3 Podcast from the April 2009 edition of Evo in the News featuring Sydnor Withers of the Great Lakes Bioenergy Research Center 
Table 1 Evo in the News articles retrieved by general searches for the topics of speciation, behavior, DNA, and biodiversity

\begin{tabular}{lll}
\hline Search term & Articles & Publication date \\
\hline Speciation & Evolving conservation strategies & June 2007 \\
& Happy 200th, Darwin! & February 2009 \\
& Sex, speciation, and fishy physics & Marcy 2009 \\
Behavior & Cheating cheetahs prosper & July 2007 \\
& Evolution's dating and mating game & May 2008 \\
& Quick bites and quirky adaptations & October 2006 \\
& Quick evolution leads to quiet crickets & December 2006 \\
DNA & Evolution at the scene of the crime & March 2006 \\
& Genealogy enthusiasts mine DNA for clues to evolutionary history & November 2007 \\
& Ghosts of epidemics past & October 2008 \\
& Got lactase? & April 2007 \\
& Seeing the tree for the twigs & May 2007 \\
Biodiversity & Evolving conservation strategies & June 2007 \\
& Hotspots for evolution & June 2006 \\
& Tough conservation choices? Ask evolution & December 2008 \\
& Where species come from & November 2006 \\
\hline
\end{tabular}

\section{Evo in the News in Your Classroom}

The tools described above are designed to ease classroom implementation by providing teachers with a flexible suite of resources that they can deploy according to their needs and preferences. Some teachers may wish to use Evo in the News as it comes out every month, in order to bring current events into the classroom and incorporate evolution throughout the semester or school year. Others may choose to match selected news items to particular topics in their curricula. For example, a lesson about how genes code for proteins might be supplemented by the April 2007 news story on the evolution of lactose tolerance, which addresses the same topic; a lesson on the immune system could be supplemented by the March 2007 news story on why HIV presents such a challenge to vaccine developers; and a lesson on classification could be supplemented by the March 2008 story on the discovery of a new mammal species and how the classification of that group of organisms has changed over time as scientists have learned more about their evolutionary history. To locate Evo in the News items appropriate for a specific topic, visit the Understanding Evolution general lesson search engine (http://evolution.berkeley.edu/evosite/search/search.php), enter the topic of interest in the keyword search box, and select resources tagged "Evo in the News" (Table 1). To locate Evo in the News items that deal with particular evolutionary concepts, visit the concept search engine, find the grade level and concept you are interested in teaching, select "See Lessons," and view resources tagged "Evo in the News" (Table 2).

Evo in the News can be used in the classroom in many different ways - as take-home assignments, as the topic of small group discussions, as a departure point for an activity or class discussion, or as the starting point for individual or group research projects. This might be as straightforward as having students read a news brief, watch the podcast as a class, and turn in their answers to the discussion questions. Other teachers might prefer a more elaborate and open-

Table 2 Evo in the News articles retrieved by sample 9-12 concept searches

\begin{tabular}{|c|c|}
\hline Concept: articles & Publication date \\
\hline \multicolumn{2}{|c|}{$\begin{array}{l}\text { Depending on environmental conditions, inherited characteristics may } \\
\text { be advantageous, neutral, or detrimental: }\end{array}$} \\
\hline Another perspective on cancer & October 2007 \\
\hline Evolution from a virus's view & December 2007 \\
\hline Ghosts of epidemics past & October 2008 \\
\hline Got lactase? & April 2007 \\
\hline Quick evolution leads to quiet crickets & December 2006 \\
\hline Sex, speciation, and fishy physics & Marcy 2009 \\
\hline Superbug, superfast evolution & April 2008 \\
\hline \multicolumn{2}{|c|}{$\begin{array}{l}\text { The amount of genetic variation within a population may affect the } \\
\text { likelihood of survival of the population; the less the available } \\
\text { diversity, the less likely the population will be able to survive } \\
\text { environmental change: }\end{array}$} \\
\hline Cheating cheetahs prosper & July 2007 \\
\hline Evolution down under & September 2008 \\
\hline Warming to evolution & July 2006 \\
\hline \multicolumn{2}{|c|}{ Evolution may occur as a result of genetic drift: } \\
\hline Evolution at the scene of the crime & March 2006 \\
\hline \multicolumn{2}{|c|}{$\begin{array}{l}\text { The similarity of DNA nucleotide sequences can be used to infer the } \\
\text { degree of kinship between species: }\end{array}$} \\
\hline Evolutionary evidence takes the stand & January 2007 \\
\hline The new shrew that is not & March 2008 \\
\hline
\end{tabular}


ended implementation. For example, over the course of a few weeks, students and their teacher could explore several different news briefs. The teacher could then provide students with a popular press story with a hidden evolution connection and ask students to research and write a short explanation of this connection. Or students could be challenged to find their own news stories with an evolution connection and present them to the class. The possibilities are wide-ranging, and the supplementary teaching tools that come with each news brief are designed to support a variety of implementations.

\section{Future Directions}

Evo in the News has responded and will continue to respond to teacher needs. In a formative evaluation of the program (Rockman et al. 2005), teachers reported that they were likely to use Evo in the News in their classrooms but that the utility of the briefs could be improved with study questions and additional support materials. In response, discussion questions and links to supporting lessons, activities, and readers were added. In a small-scale survey of the podcast component of Evo in the News, both teacher and students gave the podcast a positive rating but reported preferring shorter podcasts. In response, podcast length has been adjusted.

A more formal assessment of Evo in the News is currently underway in collaboration with the University of North Carolina, Chapel Hill, School of Education. It aims to assess the accessibility of the program, its effectiveness at increasing student understanding of evolutionary concepts, and its effectiveness at communicating the relevance of evolutionary theory. This evaluation will provide critical feedback for future improvements in the program. Information about participating in the evaluation can be found on the NESCent and Understanding Evolution websites. To keep up-to-date with Evo in the News as it evolves, subscribe to Understanding Evolution's free e-letter.

Evolutionary concepts are central to basic science literacy (American Association for the Advancement of Science Project 2061 1993) and, increasingly, have applications in people's everyday lives (e.g., in making consumer choices about genetically modified foods, purchasing an antibacterial soap, or voting on conservation issues) and in scientific advancement in other fields (e.g., medicine, chemical engineering, and even software design). By bringing Evo in the News into your classroom, you can provide your students with a ready answer to why they need to know all this evolution stuff anyway: because evolution is everywhere - and because it really matters in our everyday lives!

\section{Useful Links}

- Education and outreach at The National Evolutionary Synthesis Center: http://www.nescent.org/eog/

- Evo in the News archive: http://evolution.berkeley.edu/ evolibrary/news/newsarchive_01

- Evo in the News subscription service: http://evolution. berkeley.edu/evolibrary/subscribe/email_signup.php

- Keyword search for lessons and news items: http:// evolution.berkeley.edu/evosite/search/search.php

- Concept search for lessons and news items: http:// evolution.berkeley.edu/evosite/Lessons/IIConcepts.php

Acknowledgements The author wishes to thank Judy Scotchmoor and Kristin Jenkins for helpful comments on an earlier draft.

Open Access This article is distributed under the terms of the Creative Commons Attribution Noncommercial License which permits any noncommercial use, distribution, and reproduction in any medium, provided the original author(s) and source are credited.

\section{References}

American Association for the Advancement of Science Project 2061. Benchmarks for science literacy. New York: Oxford University Press; 1993.

Borenstein S. Fossils challenge old evolution theory. Fox News Aug 9. http://www.foxnews.com/wires/2007Aug09/0,4670, HumandEvolution,00.html (2007). Accessed Aug 2007.

Daeschler EB, Shubin NH, Jenkins FA. A Devonian tetrapod-like fish and the evolution of the tetrapod body plan. Nature. 2006;440:757-63.

Grant PR, Grant BR. How and why species multiply: the radiation of Darwin's finches. Princeton: Princeton University Press; 2008.

Hillis DM. Making evolution relevant and exciting to biology students. Evolution. 2007;61:1261-4.

MacFadden BJ. Fossil horses-evidence for evolution. Science. 2005;307(5716): 1728-30.

National Research Council. How people learn: brain, mind, experience, and school. In: Bransford JD, Brown AL, Cocking RR, editors. Committee on Developments in the Science of Learning. Washington, DC: National Academy Press; 1999.

National Research Council. Evaluating and improving undergraduate teaching in science, technology, engineering, and mathematics. In: Fox MA, Hackerman N, editors. Committee on recognizing, evaluating, rewarding, and developing excellence in teaching of undergraduate science, mathematics, engineering, and technology. Washington, DC: National Academy Press; 2003.

Project Kaleidoscope. Report on reports II. Recommendations for urgent action: transforming America's scientific and technological infrastructure. Washington, DC: PKAL; 2006. http://www.pkal.org/ documents/ReportOnReportsII.cfm. Accessed May 2009.

Rockman et al. New features teacher web site on evolution. Understanding Evolution. http://evolution.berkeley.edu/evolibrary/documents/ New_Features.doc (2005). Accessed May 2009.

Spoor F, Leakey MG, Gathogo PN, Brown FH, Antón SC, McDougall I, et al. Implications of new early Homo fossils from Ileret, east of Lake Turkana, Kenya. Nature. 2007;448:688-91.

Thewissen JGM, editor. The emergence of whales, evolutionary patterns in the origin of Cetacea. New York: Plenum; 1998.

Worobey M, Gemmel M, Teuwen DE, Haselkorn T, Kunstman K, Bunce M, et al. Direct evidence of extensive diversity of HIV-1 in Kinshasa by 1960 . Nature. 2008;455:661-4. 